\title{
The problems of livestock theft in Tuva: History and modernity (ethnic and legal aspects)
}

\author{
Elena Aiyzhy ${ }^{1 *}$ (D), Artysh Mongush², Aziana Mongush², Aldyn-Kherel Ondar², Shoraana Seden-Khuurak ${ }^{2}$ and \\ Ayana Bildinmaa ${ }^{2}$
}

\begin{abstract}
One of the most important achievements of the Tuvans in the process of adaptation to the nomadic culture and to the extreme continental climate of Central Asia was the breeding of various domestic animals adapted to different ecological conditions of the region. The main wealth of a nomad is livestock: horses, camels, cattle, sheep and goats, yaks, and reindeer. The article analyses the problems of livestock theft in Tuva from the mid-nineteenth century to the current state, as well as structure and dynamics of livestock theft. The main reasons for livestock theft and its reduced detection are analysed. On the basis of the conducted research, the authors have revealed a subjective portrait of a Tuvan livestock thief. Grazing as one of the factors of stock theft was studied. Suggestions on preventing livestock theft and recommendations on counteracting this crime are made.
\end{abstract}

Keywords: Tuvans, Kaigal, The system of torture and punishment tos erii, Horse thieves, Grazing

\section{Introduction}

Livestock theft crimes are deeply rooted in history. Livestock theft is not limited to a specific continent, country or region. For a long time, this phenomenon, which has no geographic reference, manifests itself in various scales and dimensions. Despite the fact that cattle theft in the twenty-first century may seem an anachronism, the fact that the problem creates a threatening effect for the economies of some countries suggests that the relevance of the issue is far from exhausted (Economist 2020; Gumba and Traore 2020). Agriculture is one of the cornerstones of many countries' economies. Therefore, it is in the interests of states to create all the necessary conditions to prevent and ensure the investigation of crimes committed in rural agricultural communities, taking into account their destructive impact on the economy and, consequently, food security of a country (Clack 2013).

\footnotetext{
* Correspondence: e.aiyzhy@rambler.ru

${ }^{1}$ Department of World History, Tuvan State University, Lenin str., 36, Kyzyl,

Russian Federation 667000

Full list of author information is available at the end of the article
}

The role of animal husbandry in agriculture has always been exceptional. According to the Food and Agriculture Organization (FAO), livestock accounts for $40 \%$ of the world's agricultural value and provides livelihoods as well as food and nutritional security for nearly 1.3 billion people (World Bank 2020). At the same time, for some countries and regions of the planet, the role of livestock in the agricultural sector can be vital. Therefore, the fight against crime in this industry requires special attention. The criminal law systems of different countries differ in the legal definition of livestock theft; examples are stock theft (South Africa), cattle raiding (European countries and the USA), cattle rustling (East and North Africa), lifting (India), and cattle duffing (Australia) (Clack 2018a).

In most states, criminal legislation provisions on crimes threatening or endangering life, health, and property reflect a state's response to the most common socially dangerous acts. At the same time, despite some similar approaches to the legal regulation of responsibility for these crimes, the criminal legislation of any state 
has certain features, the study of which allows one to learn a different foreign experience, identify its positive qualities, and improve the domestic legal system.

In the Russian Federation (RF), at the present stage, theft is considered the most common type of crime (Goncharova 2020). In this regard, RF's contemporary criminal law mainly focuses on theft. It attracts the attention of all internal affairs departments and criminal law theorists (Karpova 2011; Dovgan and Morozov 2020). For effective crime prevention measures, knowledge of an offender's personality characteristics is an indispensable condition.

The study of an offender ${ }^{1}$ is of great importance for the effectiveness of the disclosure and investigation of any crime. Meanwhile, a criminal's personality structure can be understood only on the basis of complex and comprehensive research. The structure of a criminal's personality is a system of social characteristics and the relationship between different types of these social characteristics. The system of social characteristics includes demographic and socio-psychological individual features (Antonyan et al. 2017; Yochelson and Samenow 1993). Stock thieves often take measures to disguise criminal activity and oppose the detection work. These types of property crimes are usually associated with lengthy preparation for criminal trespass and constructive group criminal activity, and they often are well-organized. Therefore, in the course of the pre-trial investigation, difficulties arise not only with establishing the circumstances of the crime committed, but also with obtaining information about the person that committed the crime. The actions of livestock thieves cause increased public resonance, undermine people's faith in the ability of law enforcement bodies to fight this type of crime and to protect their livestock from criminal encroachments. Taking into account the right protected by law to the inviolability of private property, the main role in the fight against cattle theft is assigned to law enforcement agencies and operational, investigative, and, accordingly, preventive activities. Herewith, of importance are constitutional acts as a guarantor of the principle of inviolability of private property. Unfortunately, the internal affairs bodies do not always take adequate measures to fight livestock theft (hereinafter terms "livestock theft", "theft of livestock", "animal theft" mean the same and are used interchangeably). Such factors as the originality of group criminal activity, its dynamism, and variability are not always taken into account. This is not only due

\footnotetext{
${ }^{1}$ In Russian and post-Soviet states' legal science, the concept of "criminal personality" ("Identity") is used more often. It implies a set of socio-psychological properties and qualities of a person, which are the reasons and conditions for committing crimes. In Western law, a similar definition is also present, but it has a more limited application and semantic connotation. See Antonyan et al. (2017) and Aylor (2009).
}

to the lack of a professional core, but sometimes to the weak methodological support, and the absence of effective scientifically-based recommendations.

The economic situation in the Republic of Tuva (Russian republic) is associated with the agro-industrial complex, mainly with grazing. This form, firstly, is due to the natural and climatic conditions and the landscape of the area under consideration, one of the features of which is the low temperature drops in winter, which make it impossible to keep animals in open pens. Secondly, there are not enough hayfields to procure forage for animals on the territory of the Republic of Tuva. All these circumstances in contemporary Tuva caused in the distant past the people's need to raise animals by using distant pastures, which in turn became a premise of such a phenomenon as "livestock theft" (Mongush 2019a). The urgency of the problem of open access livestock grazing provoking the commission of crimes was noted in 2018 by the current Minister of the Ministry of Internal Affairs for the Republic of Tyva. According to him, half of all cattle thefts were committed precisely due to open access grazing. During the Regional Conference on combating crime in Tuva Republic, the Minister noted that in the history of Tuva Republic, an increase in cattle thefts occurred during the Second World War years, which was associated with socio-economic reasons. During 1921-1924, cattle theft was a very rare phenomenon. In the post-war period, the peak of thefts was in 1999, when more than 120 thefts were registered. It was during these years that the highest inflation and the fall in the standard of living occurred. However, since that period, the problem of cattle theft in Tuva Republic has not disappeared. At the same time, technological advances and information and communications technologies (ICTs) have expanded the toolbox of crime, providing criminals with new opportunities (Official portal of the Republic of Tuva 2018).

The relevance of our study is connected with the unsatisfactory state of the fight against livestock theft in RF, a transboundary context of the problem, the incompatibility of such a phenomenon as livestock theft with the concept of the rule of law, and inviolability of private property in contemporary society. The purpose of the research is to define the determinants and historical prerequisites for cattle theft in Tuva Republic and develop scientifically substantiated proposals for improving criminological counteraction to livestock theft in Tuva Republic. The study discusses a number of tasks that need to be solved:

1) To consider social aspect of responsibility for animal theft

2) To reveal the social portrait of a livestock thief in the past and at the present stage 
3) To develop the necessary recommendations to improve the criminal law and other regulations in terms of enhancing the effectiveness of counteracting animal theft

4) To formulate a set of measures of a general social and special criminological nature aimed at preventing animal theft.

\section{Literature overview}

Based on the review of contemporary research, it is noted that the issue of livestock theft is not the prerogative of any particular region or continent. Livestock theft has been reported in both developing (Nigeria, Lesotho) and developed countries (the USA, the UK) (Clack 2018b). However, in terms of damage to the economy of a country or region, the consequences of crimes related to livestock theft can be radically different.

Animal theft is mainly relevant exactly in areas where it happens in large numbers. Livestock theft is a pressing problem in some African countries. This is evidenced by many studies on solving this problem in this region. Contemporary research on African states is devoted to such issues as the possibility of using contemporary IT technologies to prevent livestock theft (Dieng et al. 2017), livestock as a reason for serious conflicts between organized crime groups in northern Nigeria (Olaniyan et al. 2016), the problem of livestock theft, and the preventive measures taken in the state of Kaduna, Nigeria (Bashir et al. 2018). However, research on livestock theft and its countermeasures goes far beyond the African region.

Contemporary research on combating livestock theft in the world is devoted to such issues as the effectiveness of law enforcement and trust in the authorities, for examples of South Africa and the UK (Clack 2018b), the analysis of livestock theft cases from the standpoint of criminological theories (Clack 2015), impact of livestock theft on household poverty in developing countries (Khoabane and Blac, 2009; Clack 2018a), and typology of criminals in the meat supply chain (Manning et al. 2016).

Livestock theft committed in the Republic of Tuva has its own features associated with history, traditions, religious beliefs, etc. Tuvan-specific studies address such issues as:

- The use of contemporary digital means to identify the determinants of theft in the field of animal husbandry (Alexandrova and Zheludkov 2019)

- Analysis of the practice of investigating the facts of cattle theft (Mongush 2019a)

- Forensic features of livestock (Shcheblyakov 2020)

- Economic and legal characteristics of the crime rate in Tuva (Dabiev 2018)
The issue under research, from a criminal law point of view, is considered from two aspects: first, the grazing of farm animals as a condition to the commission of crimes related to livestock theft, and second, the identity of the offender and the factors involved in criminal activities related to theft of farm animals.

In contemporary studies in the Tuvan context, it is noted that the detection of cattle thefts depends on the proper material and technical equipment (an aspect that constitutes a problem for the Tuva region), the skills of the operational staff, the ability to communicate with the population and pastoralists, and recognizing livestock by their appearance. The studies note that proving the guilt of livestock thieves is complicated by such factors as: a lack of specialists in forensic science; an increase in the volume of apparatus functions in the operational and service activities of police units, including regional internal affairs bodies, a lack of sufficient work experience among a number of criminal investigation officers and high staff turnover. The most effective methods of preventing livestock thefts are considered to be carrying out raids and identifying the purchase or sale of stolen goods. However, at present in Tuva, this activity is organized in an inappropriate manner (Mongush 2019a, 2019b).

In studies devoted to forensic characteristics of livestock theft using the example of the Republic of Kazakhstan (belonging to the same sub-region and being a state where the problem applies as well), it is noted that the essential features of persons engaged in cattle theft are a relatively stable relapse, committing crimes in a group, leading a "parasitic" lifestyle, and a pronounced "male" type of crime (Khanov and Birzhanov 2016). According to contemporary research data, most livestock theft crimes, both in the border regions of Tuva and in others, are due to unsupervised livestock grazing. Animals are more often stolen from open access grazing areas, i.e. where criminals see "favorable" conditions for this - remoteness from settlements, lack or paucity of guards. It is noted that, as a rule, thefts are committed by organized criminal groups. More than half of all livestock thefts in the region were committed by local residents as part of groups (Mongush 2019b; Shcheblyakov 2020).

\section{Review of the historical background of cattle theft in Tuva in the regional context}

Livestock theft as one of the problems of agriculture is a pressing aspect of human activity, which affects the interests and feelings of many people; it is reflected in the moral, ethical, social, and economic life of society. Livestock theft is one of the most pressing topics: farm animals are stolen in different regions of Tuva every year. After the collapse of the USSR (the Union of Soviet 
Socialist Republics) in 1991, in Tuva, as in the entire post-Soviet space, the number of crimes, including livestock theft, increased. One of the reasons was that theft turned out to be the easiest, and sometimes, it was the only way to feed oneself and one's family (Kisel 2018).

Farm animals, being the main source of income for Tuvans from ancient times, became the subject of criminal encroachment. Since 1999, when crime peaked, livestock thefts have almost quadrupled. According to the Information Center of the Ministry of Internal Affairs of the Republic of Tuva, in 2019, 476 crimes related to theft of farm animals were registered. Five hundred forty-nine head of cattle, 517 horses, and 582 head of small livestock were stolen, as well as a small number of thefts of pigs and yaks. Citizens' criminal offences caused material damage of more than 86 million rubles (approx. $\$ 1,17 \mathrm{~m}$ ) (Ministry of Internal Affairs for the Republic of Tyva 2021).

It should be noted that livestock theft in RF is widespread not only in the Tuva region. For example, in studies devoted to horse stealing as part of animal stealing, it is noted that RF's Bashkortostan, Chelyabinsk, Orenburg, and Irkutsk regions are now considered to be areas of widespread horse stealing (Galieva 2017; Galieva 2019).

However, in the other regions, crimes related to livestock theft, as a rule, are caused by a common mercenary motive-obtaining material benefits by selling stolen goods. In this context, the crimes of animal stealing that take place in Tuva may be caused by other motivesmotives that have historical and cultural roots. In addition, the geographical features of the area of criminal activity-the border region, contributing to the transfer of livestock across the border of RF and Mongolia-are also important. Cattle theft and smuggling (primarily meat) are a significant problem for law enforcement agencies on the Tuvan section of the Russian-Mongolian border. Due to the huge length of the border between the Republic of Tuva and Mongolia in sparsely populated areas, as well as the lack of border protection, the issue of animal theft takes on a crossborder context (Mongush 2019b).

Turning to the geography of the region and the historical context, it should be noted that the Republic of Tuva is a subject of RF, a republic within it. Tuva is a part of the Siberian Federal District. It is located in the upper reaches of the Yenisei River, in the geographical centre of Asia. Mountains occupy $82 \%$ of the territory, while in the centre is the flat Tuva depression. Tuva borders Mongolia to the south, as well as five constituent entities of RF: the Republic of Altai, the Republic of Khakassia, the Krasnoyarsk Territory, the Irkutsk Region, and the Republic of Buryatia. From 1758-1911, Tuva was a province of China and from 1912-1918 under a protectorate of RF. On June 18, 1918, the independent state of Tannu-Tuva was proclaimed; after the revolution on June 18, 1921, it became an independent Tuvan People's Republic-the first socialist state after Soviet Russia. On October 13, 1944, the Tuva People's Republic voluntarily became part of the Russian Soviet Federative Socialist Republic as an autonomous region (Weinstein 1991; Official portal of the Republic of Tuva 2021).

The contemporary population of Tuva is 324,400 thousand people. The administrative-territorial division includes 143 municipalities, of which: 17 municipal regions, 2 city districts, 4 urban settlements, 120 rural settlements (Official website of the Plenipotentiary Representative of RF President n.d.). The products of the agricultural sector in the Republic occupy the largest share, accounting for almost $70 \%^{2}$. In 2015 , crop production accounted for 17.7\%, livestock-82.3\% (Expert and Analytical Center of Agribusiness "AB-Center" 2015). Agricultural lands occupy more than $20 \%$ of the territory of the Republic (Federation Council of the Federal Assembly of $R F$ ). Due to natural and climatic conditions, the traditionally dominant branch of agricultural production is animal husbandry, amounting to $84 \%$ of products (Oorzhak 2019). The largest number of small ruminants is in Sut-Kholsky and Ovyursky municipal districts (114-162 thousand heads), then Kyzyl, TesKhem, Bai-Taiginsky, Dzun-Khemchiksky and BarunKhemchiksky municipal districts (67.5-113 thousand heads). The largest number of cattle is in Kyzyl, BarunKhemchik and Dzun-Khemchik regions from 11.8 to 15.6 thousand heads. The leader in terms of horses is the Kyzyl region - more than 8 thousand heads, then Barun-Khemchiksky and Dzun -Khemchik region - more than 6 thousand, Erzinisky, Piy-Khemsky, Sut-Kholsky about 4 thousand (Bicheool et al. 2016). The agriculture of the Republic is represented by 42 thousand personal subsidiary plots: they account for $76.0 \%$ of the livestock of cattle, sheep and goats - $47.3 \%$, pigs - $82.2 \%$; also 1650 legal entities including: 1133 heads of peasant (farmer) households and individual entrepreneurs, 517 agricultural organizations of regions. ${ }^{3}$ As of 2018, 7309 people were employed in agriculture, hunting, forestry,

\footnotetext{
${ }^{2}$ Resolution of the Government of the Republic of Tuva dated November 22, 2019 No. 553 "On approval of the Strategy for the development of the agro-industrial complex of the Republic of Tuva for the period until 2030" http://publication.pravo.gov.ru/Document/ View/1700201911290012?rangeSize $=10$

${ }^{3}$ Ministry of Agriculture and foodstuffs of the Republic of Tuva. Project of the STRATEGY DEVELOPMENT OF THE AGROINDUSTRIAL COMPLEX OF THE REPUBLIC OF TUVA UNTIL 2030 https://mcx.rtyva.ru/upload/files/0fb65639-53b6-4fae9b01-83876c32f51b.pdf
} 
fishing and fish farming ${ }^{4}$. Although to date there are no reliable data on the exact number of shepherds in the Republic, in 2013 the register of shepherds-thousanders (a shepherd who has a thousand cattle) included 50 people (Official portal of the Republic of Tuva 2014). A high share of shadow employment is typical for Tuva, in the informal sector of the economy of which more than 30 thousand people are employed (about 23\% of the economically active population), mainly in agriculture and the sphere of wholesale and retail trade (Oorzhak 2020). According to the latest official data from the Ministry of Internal Affairs, facts related to livestock thefts were registered in all regions of the Republic, with the exception of Tere-Kholsky (Ministry of Internal Affairs in the Republic of Tuva 2018).

The problem of livestock theft in Tuva is deep-rooted. A lot of works by Russian and foreign authors have been written on livestock theft and responsibility for it in Tuva and the Central Asian region. Thus, Frederic Constant in his works reviewed the legal system of the Qing Empire and the attitude of Qing officials to the customary law of the Mongols. In his opinion, Qing officials enacted harsh punishments for animal theft and considered this problem a serious threat to social stability in Mongolian society (Constant 2019). Researchers Jusupov and Orozov (2018) conducted a study in Kyrgyzstan, where the problem of livestock theft is still relevant. They studied contemporary measures to fight stock thieves. Authors Botash and Zhappasov (2020) wrote about trade relations between Kazakhstan and RF in the sixteenth to eighteenth centuries, where the problem of livestock theft is also mentioned. Exploring the origins of cattle theft in Tuva in the context of regional peculiarities, the authors note that cattle theft was widespread among the Kazakh nomadic tribes. From about the middle of the seventeenth century, the Kazakh nomadic nobility often attacked Russian merchants, capturing prisoners and stealing cattle.

\section{The issue of livestock theft in Tuva in Russian pre- revolutionary and interwar period studies}

In the pre-revolutionary Russian historiography of the issue, one of the first scientists who briefly touched upon Tuvan livestock theft was the geologist P.A. Chikhachev (Chikhachev 1974), who noted that the phenomenon of stock theft was developed not only among Tuvans, but also among neighbouring nomadic peoples, such as Kachin people (Chikhachev 1974).

Orientalist and Turkic peoples' researcher V.V. Radlov, who visited north-western Tuva in the area of lake KaraKhol and river Alash in 1861, cited information

\footnotetext{
${ }^{4}$ See Resolution of the Government of the Republic of Tuva dated November 22, 2019 No. 553 http://publication.pravo.gov.ru/ Document $/$ View $/ 1700201911290012$ ? rangeSize $=10$
}

concerning the methods of livestock theft. People who intended to steal horses would undress and crawl to them on their stomachs, silently untie them, jump on them, and gallop away. There was also the second group of thieves that would stay with the remaining horses and wait for the owner to run after the first group of thieves. When the owner ran after the stolen (by the first group) horses, this second group of thieves would steal the remaining horses (Radlov 2007). It is noteworthy that both V.V. Radlov and G.N. Potanin (1895) gave similar information about the Tuvan horse thief, describing the appearance and clothing of Tuvan men, including horse thieves, and they paid attention to practicality of their clothing. Horse thieves were mobile, used a minimum of clothing so that there was no "smell", and during the pursuit, they could easily escape.

According to A.V. Adrianov (1886). who had an expedition to Tuva in 1881, theft was a common vice for all Soyots (outdated name of a Tuvan), starting with the officials themselves and ending with the last poor man. Theft and robbery were committed day and night, sometimes right in front of the owners, and they often did not cause censure and persecution. Theft had become commonplace (In fact, theft in Tuvan society has never been encouraged; in this regard, there is a well-known expression oоrnи огии ти gash, which is literally translated as "the way of a thief leads to a bad end". It is most likely that this information referred to Tuvans, who committed crimes against visiting merchants. Most informants for the researchers were Russians, who unflatteringly spoke about local residents (Adrianov 1886). A.V. Adrianov here described one of the methods of punishment, which was part of the system of torture and punishment tos erii (mос эрээ-“nine tortures"). In reality, there were many more of them.

There is a more detailed description of torture in the work of E.K. Yakovlev 1900. Torture was a necessary part of the investigation, or rather, the investigative procedure consisted of a whole system of physical and moral torture. However, usually naive and simple-minded Soyot, fallen on trial for some trifle, tried to confuse the case, despite the fact that he had to endure serious torture. "There is no mountain without a wolf; there is no man who does not have a trick!"-says the Soyot proverb [пюр джоx, maг $\left.\partial \varkappa о x, ~ м е г э ~ \partial ж о х, ~ и р ~ \partial \varkappa о x^{5}\right]$. Only women were exempt from torture. Despite the fact that written sources explaining the inapplicability of torture to women have not survived, it is permissible to assume that this is due to

\footnotetext{
${ }^{5}$ Taking into account the well-established norms of transliteration this expression sounds like pyur joh, tag jock, mege joh, ir joh. Since the information presented in Russian (Yakovlev 1900) was taken as a basis, here and below the extended transliteration used in translation from Russian into English is given. Considering the peculiarities of phonetics, the correct pronunciation of words may differ from that presented in other sources, in particular, Mongush (1999).
} 
the absence of precedents and the traditional role of a woman-mother in a patriarchal society (Natsak 2021).

The following grade of several stages of physical torture was distinguished-ereler (эрәлер):

1) shagai (maгaŭ)-slaps in the face with a long leather mallet

2) khaak (xak)-stick strikes on the backside

3) manza (манза) - stick strikes on leg muscles

4) sas khylga (сасхылгza) - tightening and twisting of the fingers

5) ten sogar (пэн согар)-hammering thorns under the nails

6) ooryskar (oоpыскар) - a board was put on the neck and hands, and a person was to be eaten by mosquitoes, flies, and parasites

7) sooduk (ссодyк)-shake on the rack

8) yshtar (blumap) - one who did not confess up to three times was tied up into a yurt filled with carbon monoxide, corked up, and then pulled out half-dead

However, for the Soyot, nine other moral tortures, or chagan (чаган), were much more terrible. One who did not confess was forced to (1) drink from a dog skull; (2) drink from a camel skull; (3) drink from a human skull; (4) swear-as khynar (ac хbынар); (5) urinate on fire and salt, under fear of getting a venereal disease if a lie was told; (6) sniff the bear's nostrils-хаяркан думчу окча (hayarkan dumchu okcha), and lick his paws-хаяркан джилга (hayarkan jilga) for fear of being eaten by a bear; (7) lick the knife blade; (8) lick the barrel of a gun; and (9) nyжар чаган-puzhar chagan ("filthy oath"); the torture meant crawling between two stakes with the pants of an old, "damned" (never given birth) woman (Yakovlev 1900). As for the punishment for livestock theft, he noted that animal theft was not a crime: if a thief was caught red-handed, then he was punished, the stolen animal was taken away, and the thief was fined in favour of the investigating official (Yakovlev 1900).

Grum-Grshimailo (1926) noted that in relation to "grave criminals and incorrigible thieves", punishments were applied in the form of cutting off arms or legs or imprisonment for up to several months in the so-called karabazhin. Valuable ethnographic materials were recorded by the researcher N.F. Katanov, who was in Tuva from December 1888 to the fall of 1889. In his work "Essays on the Uryankhai Land", a meeting with a horse thief was recorded. "One armless Soyot, seeking tobacco, bowed to my feet three times. Having received the tobacco, he put on his cap and left at once. I found out that this Soyot lost his hand for horse theft" (Katanov 2011). The practice of using torture and corporal punishment for crimes disappeared in Tuva with the annexation of the territory to
Tsarist Russia. In 1914, the tsarist government declared a Russian protectorate over Tuva. Under the name of the Uryankhai Territory, Tuva was administratively subordinate to the Yenisei province. Penalties for robbery were established depending on the severity of the crime: the death penalty, hard labour, reference to hard work at post stations. When imposing responsibility, both the number of criminals and the degree of participation in robbery were taken into account (Kiseleva 2012).

Among the pre-revolutionary authors, F. J. Kon (Kon (1936) tried to explain the Tuvan livestock-stealing from a historical point of view and believed that it might be a part of the form of baranta (the capture of livestock from the Turkic nomadic peoples as a way of revenge for an insult or reward for damage caused) that has survived from ancient times. Like other researchers, wrote that the Tuvans stole horses and cattle from the Russians. This was done so skillfully that it was never possible to find the culprit. Thus, in pre-revolutionary times, researchers and travellers who visited Tuva for the most part wrote that the Tuvans had developed livestock theft. Cattle thefts had two motives, according to the ethnic names of the crime: Oorlaashkyn and tut$k_{u u s h}{ }^{6}$. Oorlaashkin pursued economic goals, while tutkuush regulated social and ethnic conflicts. The main desire of the livestock thieves was not to increase their own property or punish the offender, but to strengthen their personal authority in their native community, so as to raise their social status (Kisel 2018).

The study of the problems of Tuvan livestock theft will not be complete without considering the image of the kaigals. The image of the Tuvan kaigal is very complex and contradictory. It cannot be said that the kaigal is definitely a thief and a swindler. If this was the case, then Tuva would not have many bearers of such names. For example, the famous performer of Tuvan folk songs, master of throat singing Kaigal-ool Khovalyg is an Honored Artist of RF. The inconsistency is revealed in the dual meaning of the term kaigal. In the Dictionary of the Tuvan Language, the term kaigal is defined in two senses: in a positive assessment as "a daredevil, daring, desperate person" and in a negative one-"a thief, deceitful, rogue person, a rogue" (Mongush 2011).

Kisel (2018), who also studied the image of the kaigal, mentioned that among many peoples, livestock theft was considered not only a daring act but also a feat. If one considers the image of the kaigal from a militaryhistorical point of view, then it appears as a scout, a saboteur who weakens the enemy's troops. Having stolen a herd of horses, horse thieves could inflict great damage on the enemy. That is why the presence of such capable people was a necessary condition for military superiority.

\footnotetext{
${ }^{6}$ In Russian, Оорлаашкын and туткууш.
} 
In the "Secret Legend of the Mongols", it is noted that Temujin himself, the future Genghis Khan, had to get his horses back: "Once robbers appeared and stole eight night geldings located not far from the yurt ... Temujin sat down on his greyish horse and followed the trail left on the grass by the night geldings ... and managed to get his horses back" (Kozin 1941).

The Tuvans have an expression: "They recognize a windy place by the trees, the kaigal - by the eyes". The word kaigal has a positive connotation here. In this expression, kaigal is the closest in meaning to dzhigit, daredevil.

\section{Materials and methods}

The article used contemporary theoretical and methodological foundations of legal anthropology. The current approach implies studying the rules of human behaviour in society, with the emphasis on the legal aspect, which is closely interconnected with other elements of the cultural and social systems of society. The study used the historical and legal method, which made it possible to objectively consider animal theft in traditional Tuvan society. The applied method made it possible to trace the context, origins, evolution of a criminal act, motives for committing crimes, qualifying features, and features of criminalization. Considering the interdisciplinary nature of the research, it was also decided to apply an integrated approach, which draws on data from related sciences-sociology, psychology, folklore studies, linguistics, and cultural studies. This made it possible to analyse animal theft in the entire set of its manifestations. The instrumental component of the method is based on desk review of the collection and analysis of secondary information about the research object from open sources. This study covered all regions of Tuva Republic (17 municipal regions).

Specific sociological research methods involved studying materials from criminal cases and interviewing respondents. In particular, 63 employees of five intermunicipal departments of RF's Ministry of Internal Affairs in Tuva Republic were interviewed:

- Thirty-two operatives directly involved in the disclosure of livestock thefts

- Twenty-eight investigators involved in the investigation of this type of crime

- Three heads of the internal affairs bodies of the district level, responsible for organizing the disclosure and investigation of theft of farm animals

The choice of respondents was determined due to the competence of these officials and their practical experience. In the course of the interviews, the respondents were asked questions related to professional assessment and empirical data regarding the reasons and motives for livestock theft, criminological portrait of the offender, and the characteristics of criminal activity in the Republic.

In the study, we interviewed $50 \%$ of operational officers and investigators of five internal affairs bodies at the district level, out of five available in the Republic of Tuva. Establishing the share of latent thefts of farm animals is not possible due to the uncertainty of the respondents' answers. For the study purposes, the respondents' answers to questions $3-8$ were summarized in the form of a table (Table 1).

The research methodology was based on individual interviews to collect qualitative data (based on the typology "focus analysis"-the respondent acts as a source of information). The interviews were semi-structured in nature, which is a combination of structured interview and free conversation. With regard to the research objective, the choice of the semi-structured interview method was dictated by its flexibility with the possibility of obtaining more accurate data in describing the context of the problem. The sample of respondents was

\section{Table 1 Findings from interviews on livestock theft (questions 3-8)}

Q. 3: In your opinion, what is the main reason(s) of livestock thefts?

A.1) (53 respondents) lack of proper legislative regulation obliging livestock breeders and authorities to organize (and regulate organization issues) grazing, accounting, labeling, chipping (lack of legislative regulation)

A.2) (10 respondents) problems of interaction between local selfgovernment bodies and law enforcement agencies

\section{Q. 4: Under what conditions are livestock thefts most common?}

Unified answer: lack of supervision, lack of fencing of pastures

Q. 5: What are the features of persons engaged in livestock theft in the Republic of Tuva? (All the respondents gave the similar response, with a slight deviation in terms of age)

Age-from about 14 to 35 years old

Gender-male

Marital status-not married

Social status (according to the criterion of residence) — rural residents

Source of income-livestock

34 respondents named the absence of parental care in childhood and a descent from financially disadvantaged (poor) families among the additional characteristics of the cattle thief

Q.6: What is the motive for committing livestock thefts?

A.1) (63 respondents) - getting financial gain

A.2) (32 respondents) - an attempt to assert himself in society (as an additional motive)

Q.7: Where is livestock meat sold after theft?

A. 1) (54 respondents) - through accomplices ("agents")

A. 2) (35 respondents) - through wholesale and retail outlets

A. 3) (26 respondents) - via social networks, online applications 
based on professional competence. The interviews with law enforcement agencies' representatives of different ranks were held in order to ensure the greatest objectivity of the interpreted data. Based on the assumption of crimes' similarity, their causes, and other investigated factors described in the literature, we sought the prevailing trends on the issue, to obtain a competent opinion in determining the causes of farm animal thefts and related issues.

The study limitations concerning interviewed persons were due to the professional competence of the latter, special knowledge in the field of forensic science, and the personality of the criminal ${ }^{7}$. At the same time, proceeding from the criminological definition of the structure of a criminal's personality and its criminological component used in this study, conducting a study among a wider circle of respondents, presumably, would not give an objective understanding of the personality of offenders. The participants in this study were selected as respondents based on the understanding that only law enforcement officers have sufficient empirical data and professional skills in order to provide an objective picture of the nature of crimes and the identity of the offender.

\section{Results}

Nowadays, the subjective portrait of a kaigal criminal engaged in livestock theft can be characterized as follows: this is a local resident, as a rule, unemployed or having odd jobs, who has a criminal record (Mongush 2019a). In contemporary Tuvan society, there is an understanding that real kaigals no longer exist. Livestock thieves sometimes call themselves kaigals, although for the majority of law-abiding citizens they are just oorzhular- "thieves". When they go to steal, they call it among themselves kaigaldaar, as if ennobling, softening the word "steal"-oorlanyr. Thus, great changes have taken place about the image of the kaigal; from a young daredevil and protector of ordinary people, he gradually turned into a thief, livestock stealer.

Nevertheless, this characteristic introduces a positive connotation into the concept of a criminal in this context, to some extent "romanticizing" the image of a criminal. As can be noted, despite the obvious illegality and criminal punishability of the act, in this case, such condescension is due to historical prerequisites and the traditional way of life, which is difficult to radically change. The same prerequisites determine the tacitly applicable present principle of talion - equal retaliation, retribution equal to crime (to some extent modified), however, in essence, rooted far into the past (Mongush 2019a). From the aspect of the differential association of

${ }^{7}$ Based on terminology applied previously in the study. forensic theory, it can be argued that offenders are fully "a product of their environment", since a "loyal" attitude in Tuva towards farm animal theft has been cultivated for centuries. In this case, contemporary views on the deviant behaviour of thieves, the rule of law, inviolability of private property, and the very facts of the crime come into serious conflict with the usual way of life and, to a certain extent, "tolerance" to the offender. According to the crime opportunity theory ${ }^{8}$, crimes related to livestock theft in Tuva fully correspond to its main determinants, in particular, rational choice (livestock theft under these conditions, for the purpose of sale, seems to be the most obvious and acceptable way to obtain quick financial gain) and routine activities (animal husbandry as the main occupation and the main economic industry).

Primarily, it should be pointed out that livestock thefts committed from open access pastures are characterized by non-evidence since the pastures are not fenced off or protected, and when stealing farm animals, thieves drive away the livestock in all possible directions. This is especially true for the steppe areas, where, in addition to the traces of stolen animals, there are traces of other livestock grazing in this area. Therefore, it is extremely difficult to identify the stolen animals.

According to the information of the internal affairs bodies in the Republic, livestock breeders of cattle, horses, and yaks do not continuously monitor their animals during their free range grazing, thereby providing conditions for thieves to commit livestock theft. As shown by the results of interviews with employees of the internal affairs bodies ${ }^{9}$, after the theft of farm animals, the shepherds search for the missing livestock for several days, independently, on their own, believing that the animals are on the pasture, thereby providing those who have stolen livestock with sufficient time to conceal the traces of a crime. At the same time, open access grazing as the main cause of crimes related to livestock theft is officially recognized by the Ministry of Internal Affairs of the Republic (Official portal of the Republic of Tuva 2018). The preventive and explanatory work of the Ministry of Internal Affairs of the Republic is aimed at combating uncontrolled free grazing. It should be noted that the owners or their authorized persons responsible for grazing livestock may be subject to administrative penalties. In accordance with Article 5.3 of Chapter 5 of the Law of the Republic of Tuva dated December 30, 2008 No. 905 BX-2 (the Code of the Republic of Tuva on Administrative Offenses), grazing farm animals without

\footnotetext{
${ }^{8}$ Criminality Opportunity Theory is a criminological theory that assumes that criminals make rational choices and thus choose targets that offer high rewards with little effort and risk (Felson and Clarke 1998; Fennelly and Perry 2018).

${ }^{9}$ Based on the results of the interview carried out within the framework of this study.
} 
being accompanied by their owner or an authorized person entails the imposition of an administrative fine on citizens in the amount of 500 to 1000 rubles 7-14, for officials-from 1000 to 2000 rubles 4-28, and for legal entities-from 3000 to 5000 rubles 41-68 (Ministry of Internal Affairs for the Republic of Tuva 2019). One of the main reasons for the "survivability" of livestock theft is the leniency of the punishment. Livestock theft is classified as a moderate crime, so the perpetrators are often not even taken into custody. Courts issue lenient sentences with no imprisonment (Official portal of the Republic of Tuva 2018).

Another important factor contributing to livestock theft is the situation of animal meat sales. In the Republic of Tuva, there are many public catering facilities, trading platforms and other enterprises where livestock meat is bought without any special requirements for documentation, despite the existing rules for veterinary documents (Ministry of Agriculture of RF 2006). The available places of livestock meat sale allow animal thieves to freely sell the stolen animals and get good profits. Consequently, such conditions become a cause for the commission of subsequent identical crimes; criminals know that there will be no prosecution of their criminal activities by law enforcement agencies since those who buy livestock meat acquire fictitious documents and sell it in a legal way.

Based on the results of interviews with internal affairs bodies' employees, it is noted one characteristic of livestock thefts committed in the Republic of Tuva is that the meat of stolen animals is sold to certain buyers, i.e. each person or criminal group has their own accomplice who is engaged in buying and selling the stolen livestock. These people are usually relatives (Mongush 2013), or fellow villagers of criminals who have earned their trust. The buyer, through his trusted veterinarians, receives a certificate for the stolen livestock, and the meat is sold as legal to various organizations, individual entrepreneurs or to citizens, without any suspicion.

In the past few years, due to the development of the information space on the Internet, livestock meat, including stolen meat, has been actively sold through communities using instant messengers, such as Viber, WhatsApp, or through social networks, with home delivery to citizens. The latter do not impose any requirements for the documentation of livestock meat; therefore, for persons engaged in the theft of farm animals, there are comfortable conditions for bringing their criminal intent to completion.

Considering the personality of the offender and the factors underlying which type of persons are involved in criminal activities of farm animal theft, it should be noted that a feature of a livestock thief is an interest in horse riding since childhood; this was noted by $80 \%$ of the respondents from among the interviewed employees of the internal affairs bodies in the Republic of Tuva. Moreover, the thieves do not have to own livestock, including horses. They may be involved in criminal activities through other older people who have riding horses in their household, which are usually used for committing livestock theft. The age of persons involved in farm animal theft varies from 14 to 35 years old (see Table 1).

Another important factor in which a young person is involved in farm animal theft, according to $57 \%$ of respondents, is lack of parental care. The persons engaged in livestock theft often take minors under their guardianship; their relatives' children, or acquaintances left without custody or guardianship, or when their parents do not adequately fulfil their parental functions. Under such conditions, children are brought up by persons engaged in livestock theft, who in turn involve minors in criminal activities, teaching them a "criminal craft" called "livestock theft". In turn, a young person, in an attempt to prove himself and motivated to take his social position in this criminal environment, is easily amenable to training. Subsequently, children are taught all the tactics used by livestock thieves to steal and sell stolen livestock. Even at an older age, despite the repeated serving of criminal sentences and imprisonment, they continue to engage in farm animal theft.

It should be noted that a distinction of livestock thieves apart from other criminals, who have been stealing various household items since childhood, is the presence of their own families. According to the interviewed employees of the internal affairs bodies, some types of individuals who have been involved in a criminal environment since childhood do not have their own families. For example, in $99 \%$ of cases, persons involved in pickpocketing do not marry (see Table 1).

Interviews of operational officers involved in disclosing livestock thefts showed that animal thieves create local criminal networks, i.e. in each specific area or settlement, there is an organized criminal group that commits livestock theft in the same or nearby territory. The legal side of these persons' lives is often associated with breeding horses that participate in annual races in the Republic of Tuva. Each criminal group has its own leader, an organizer who is responsible for the sale of criminally-obtained animals and distribution of the proceeds. The leader, as a rule, owns the necessary vehicles for ttransportation of animal meat, owns livestock including horses, the presence of which is used, if necessary, to obtain documents such as certificates from the village administration and veterinary medicine. The leader does this under the guise of selling meat from his own animals, and he has a circle of acquaintances, including officials, who provide certain services needed for 
hiding the traces of the theft (Dabiev 2018; Mongush 2019a).

Criminal groups of livestock thieves in different settlements and areas maintain contacts with each other, for the exchange of thoroughbred stallions, for the subsequent generation of racehorse offspring, for the exchange of young novice horses, and for the sale of stolen farm animals. Another factor pushing livestock thieves to commit crimes is by transferring them to correctional colonies to contact members of their criminal group who are serving a sentence for committing theft of farm animals, property, and money. Thus, supporting their "colleagues" in the "criminal craft", they try to get confessions from other criminals and criminal communities, which is also important in the criminal environment (Dabiev 2018; Shcheblyakov 2020).

The exposure of one such criminal group requires careful preparation and implementation of a complex of operational-search measures, lasting several months, until sufficient data are obtained to bring them to justice. A typical criminal scheme of livestock theft includes the organizer and perpetrators directly committing the theft of farm animals, as well as an assistant tipper-off (accomplice) who informs about "easy prey", sometimes assisting in the theft itself and who is often one of the victim's acquaintances. The organizer knows all the members of the criminal group and gives directions and instructions to all its members, while the performers and the buyer may not know each other.

This scheme includes a courier, a previously unconvicted person who does not arouse any suspicion from law enforcement agencies, who sometimes may not even know that the livestock has been stolen by someone. Since the livestock meat is transported at night, and the person who loaded it has a dubious reputation, he may simply guess about its origin. The courier hands over the meat to the buyer and receives a certain amount from him and delivers it to the organizer, and the organizer pays everyone his share. Buyers have refrigeration equipment for storing meat. Usually, at their place of residence, they have no evidence of their involvement in the purchase of meat. They have a legal job and are not suspicious.

\section{Discussion and conclusion}

Studying the differences in the criminological portrait of a animal thief criminal in Tuva and other regions of the world, the changing landscape of crime should be noted: traditional features, to one degree or another which determine criminal motives, give way to mercenary ones. India is a striking example, where cows, recognized as sacred animals, are increasingly becoming the object of criminal encroachments (Masiola and Tomei 2015). Livestock theft in African countries, previously often associated with traditional motives, is gradually disappearing. It is being replaced by livestock theft by organized groups with prior collusion, often carried out with the assistance or with the tacit permission of local corrupt authorities (Doorewaard 2020). In this case, a clear relationship with the Tuvan example is noticeable, where ethnic motives are supplanted by pragmatic mercenary ones.

Comparing crimes related to livestock theft in Tuva and African countries, it should be noted that in the latter case, envy is often the motive for the crime. Lesotho residents often steal livestock from their wealthier neighbours: the poor are often unhappy with those who have accumulated a certain number of livestock. According to localofficials, there are cases in which thieves not only steal livestock for their own consumption or for financial enrichment, but also out of revenge. One typical example is the case of mass poisoning of livestock in 2016 in one of the farms, carried out for revenge motives (Doorewaard 2020). The history of cattle theft in the USA also has some peculiarities, rare in our time, but taking place in the past. During the Great Depression in the USA, livestock theft in the suburbs was carried out by injecting animals with anaesthesia, becoming a new criminal practice (Masiola and Tomei 2015).

It should be noted that if, in the case of Tuva, envy is noted as a motive for a crime, then cases of deliberate poisoning of animals, or their abduction with the help of anaesthesia (anaesthetics), are not recorded in contemporary sources (Mongush 2019a). The interviews conducted in this study also did not confirm the existence of such cases. It should be noted that in Tuva, animal theft is not associated with murders (typical, for example, in Kenya), which also significantly characterizes the personality of the criminal and provides additional data for the formation of his criminological portrait (Masiola and Tomei 2015). In this respect, it would be permissible to assert that the traditional attitude of Tuvans towards animals does not allow one to perceive livestock exclusively as an object of commodity circulation, but rather as an integral part of the general culture, limiting the toolkit of criminal encroachments.

Considering that criminals are resorting to the possibility of using ICTs and contemporary means of communication to sell stolen livestock products, it should be noted that ICT tools can also be a possible solution to prevent theft. In particular, the use of animal chipping seems to be a rational solution (Maphane et al. 2017). The chip can contain comprehensive information about the age, vaccinations, and the owner of the animal. Today, it is possible to install tracking devices that allow identification of the animal's movement trajectory. The main problem of using this technique is that currently in RF there are no special veterinary rules that should 
regulate the procedure, or identification requirements. However, the practice of chipping is not contrary to federal law, and the development and implementation of appropriate legal tools at the local level is acceptable. The cattle identification process is already underway in some RF regions. Separately, it is necessary to note a pilot project of the Rostov region, where on a free-ofcharge basis due to subsidies from the regional government, electronic carriers are implanted in cattle. Such procedures should be developed throughout RF, making use of radio-frequency identification. At the same time, the possibilities of radio-frequency identification of animals are compatible with the "Mercury" system used in veterinary medicine, which is intended for electronic certification of goods (supervised by the State veterinary supervision service), tracking their path of movement across the territory of RF (Shcheblyakov 2020).

In accordance with the Federal Law No. 243-FZ dated July 13, 2015, and Order of the Ministry of Agriculture of RF dated December 27, 2016, No. 589, the "Mercury" system was created to achieve the following goals:

- Automatic accounting of the incoming and outgoing volume of products at the enterprise

- Tracking the movement of a consignment across the territory of RF, taking into account its fragmentation

- Creation of a single centralized database

The absence of such means of identification may serve as a basis for a preliminary check by a law enforcement agency (Shcheblyakov 2020). Currently it is more permissible to talk about the absence of proper legislative regulation for combating livestock theft and the lack of methods for using information about chipped animals in the event of their theft.

From the perspective of situational crime prevention theory, these points are generally consistent with Western approaches that use the achievements of scientific and technological progress, e.g. ICT in preventing typical crimes, educational work, and strengthening the role of interaction with the municipal police (Harkness 2020).

Considering the similarity of crimes related to animal theft in different regions of the world compared with Tuva, however, it should be noted that there is no clear evidence of the participation of government officials in the sales chain of stolen goods, inherent, for example, in Kenya (Bunei et al. 2016). Although the existing studies on Tuva are not sufficiently relevant to assess the effectiveness of the Ministry of Internal Affairs, it is assumed that crime victims at this stage are not inclined to assign all responsibility for the state of crime solely to the authorities, due to the prevailing understanding of the particular Tuvan characteristics of animal theft. In comparison with the UK and South Africa, contemporary studies on animal theft in Tuva also do not record distrust of the Ministry of Internal Affairs or regional authorities in connection with the existence of the problem (Clack 2018b).

A review of the historical background and the analysis carried out suggests that the motives for committing crimes in Tuva have changed, while the attitude towards the image of the kaigal is also undergoing changes. This, in turn, may prospectively be reflected in the assessment of the offender's personality and the criminal-legal definition of crimes related to livestock theft. This analysis would not have been possible without a review and analysis of the Tuvan historical background.

Thefts of grazing animals in the Republic of Tuva have their own specifics. Firstly, open access grazing, although it is the only rational form of livestock farming most suitable for Republic of Tuva conditions, creates problems for economic development of the Republic's inhabitants. Secondly, the established cultural characteristics, values, and socio-ethnic orientations and attitudes of the rural population living in the Republic of Tuva become the factors involving persons, including young people and adolescents, in committing livestock thefts. When the law enforcement system does not ensure the restoration of victim's rights, the latter takes their own measures to "restore their rights", and stealing livestock from the pasture of the alleged offender is the most optimal and proportionate way to restore "justice" in respect of the harm caused. In this case, contemporary views on the deviant behaviour of thieves, perception of the rule of law, inviolability of private property, and the very facts of crimes come into serious conflict with the usual way of life and, to a certain extent, tolerance towards the offender. At the same time, the poorly developed legal framework for combating livestock theft, the lack of methods for using information about chipped animals in the event of their theft, and the lack of proper work of law enforcement and administrative bodies in relation to preventive measures become significant obstacles to counteracting these kind of offences.

Based on the study results and the identified causes and conditions of animal theft, it becomes obvious what future measures can be effective for eradicating this phenomenon, and perhaps which measures can become a model for other regions. These measures are expected to be comprehensive, including both response and prevention measures, taking into account the cultural characteristics of the region. In particular, relevant measures include chipping, raising the educational level, eliminating the glorification of the image of the kaigal, strengthening control over animal grazing, and taking preventive measures for children and adolescents, in particular, those who are not provided with parental care. 
Taking into account the information from the Internal Affairs bodies about the involvement of adolescents in livestock theft, the absence of parental care in more than half of them, the influence of traditions and historical and social preconditions, all these factors together create the need to develop a theoretical and legal basis to counteract the phenomenon of livestock theft in the region soon. The limited empirical data and research on the effectiveness and methods of crime prevention among adolescents form the basis for further research.

Increasing the effectiveness of the fight against animal theft is closely related to the need for a deep study of the circumstances and methods of its commission, including the personality traits of criminals. A detailed study has not only theoretical, but also purely applied value, as it would contribute to forming effective approaches for identifying, preventing and solving crimes committed by livestock thieves.

\section{Acknowledgements}

Not applicable.

\section{Authors' contributions}

EA, ArM, AsM, AKO, SSK, and AB contributed equally to the experimentation. $E A, A r M, A K O$, and $A B$ wrote and edited the article. ArM, AsM, AKO, and SSK equally designed and conducted the experiment. EA, AsM, and SSK studied the scientific literature about the topic. All authors read and approved the final manuscript.

\section{Funding}

The research was funded by RFBR, within the scientific project number 19012-00073.

\section{Availability of data and materials}

The datasets used and/or analysed during the current study are available from the corresponding author on reasonable request.

\section{Declarations}

Ethics approval and consent to participate

Not applicable.

\section{Consent for publication}

Not applicable.

\section{Competing interests}

The authors declare that they have no competing interests.

\section{Author details}

'Department of World History, Tuvan State University, Lenin str., 36, Kyzyl, Russian Federation 667000. ${ }^{2}$ Department of Criminal Law and Process, Tuvan State University, Lenin str., 36, Kyzyl, Russian Federation 667000.

Received: 5 July 2021 Accepted: 27 October 2021

Published online: 23 December 2021

\section{References}

Adrianov, A.V. 1886. A journey to Altai and beyond the Sayan Mountains, in 1881 on behalf of the Imperial Russian Geographical Society by a member of staff $A$. V. Adrianov. Saint-Petersburg: Slovo Publ.

Alexandrova, Irina, and Mikhail Zheludkov. 2019. Features of the use of modern digital means of identification to influence the determinants of theft in the field of animal husbandry. Legal Science and Practice 1 (45): 71-76.

Antonyan, Y., V. Kudryavtsev, and V. Eminov. 2017. The identity of the offender. Saint-Petersburg: Liters.
Aylor, Bonnie. 2009. The offender's personality: The crime scene may have a voice. Florida: University of South Florida.

Bashir, Abubakar Mohammed, Talib Azlizan, and Rohana BtYusof. 2018. Cattle rustling in Kaduna State, Nigeria: An assessment of the existing preventive approaches. International Journal of Management Research and Reviews 8 (9): 20.

Bicheool, T.N., OAKh Ertineevna, and A.R. Irgit. 2016. Geography of agriculture in the Republic of Tuva. Bulletin of Tuvan State University. Natural and Agricultural Sciences 2: 60-65.

Botash, S, and ZhE Zhappasov. 2020. Trade relations between Kazakhstan and Russia in the XVI-XVIII centuries. Vestnik of KazNU: Historical Series 83 (4): 29-38.

Bunei, Emmanuel K., Gerard McElwee, and Robert Smith. 2016. From bush to butchery: Cattle rustling as an entrepreneurial process in Kenya. Society and Business Review 11 (1): 46-61. https://doi.org/10.1108/SBR-10-2015-0057.

Chikhachev, Petr A. 1974. Journey to Eastern Altai. Moscow: Nauka Publ.

Clack, Willie. 2013. The extent of livestock theft in South Africa. Acta Criminologica 26 (2): 77-91.

Clack, Willie. 2018a. Livestock theft a global and South African perspective. Pretoria: In Red Meat Producers' Organisation Conference.

Clack, Willie. 2018b. Rural crimes: Non-reporting of livestock theft by farmers. Acta Criminologica. African Journal of Criminology \& Victimology 31 (4): 1-7.

Clack, Willie J. 2015. Criminology theories: An analysis of livestock theft cases. Acta Criminologica. African Journal of Criminology \& Victimology 28 (2): 92-106.

Constant, Frédéric. 2019. The legal administration of Qing Mongolia. Late Imperial China 40 (1): 133-173. https://doi.org/10.1353/LATE.2019.0004.

Dabiev, D.F. 2018. Economic and legal characteristics of the crime rate in Tuva: History and modern realities. Economic Research and Development 3: $70-76$.

Dieng, Ousmane, Babacar Diop, Ousmane Thiare, and Congduc Pham. 2017. A study on loT solutions for preventing cattle rustling in African context. In Proceedings of ICC Conference, 153-161. Cambridge: ACM.

Doorewaard, Cecili. 2020. Livestock theft: A criminological assessment and samplespecific profile of the perpetrators. Doctoral dissertation.

Dovgan, E.A., and N.A. Morozov. 2020. Historical aspect of the formation and development of the Russian criminal legislation on liability for theft. In Tatishchev readings: Actual problems of science and practice, 12-17.

Economist. 2020. Livestock theft is becoming more common in South Africa https:// www.economist.com/middle-east-and-africa/2020/11/19/livestock-theft-isbecoming-more-common-in-south-africa. Accessed 15 Sept 2021.

Expert and analytical center of agribusiness "AB-Center". 2015. Republic of Tuva: Agriculture of Tuva.

Felson, Marcus, and Ronald V. Clarke. 1998. Opportunity makes the thief. Police Research Series, Paper 98 (1-36): 10.

Fennelly, Lawrence J, and Marianna A Perry. 2018. Crime Opportunity Theory and CPTED. In CPTED and Traditional Security Countermeasures150 Things You Should Know, 398-399. CRC Press, DOI: https://doi.org/10.1016/B978-0-12809485-3.00001-6.

Galieva, F.G. 2017. Equestrianism as an ethnosocial phenomenon on the example of Bashkiria: An experience of history in the context of modernity. Contemporary Research on Social Issues 9 (3-1): 178-196.

Galieva, F.G. 2019. Horse stealing custom in the history of some regions of the country. Bulletin of the Academy of Sciences of the Republic of Bashkortostan 30 (1): 12-20.

Goncharova, M.V. 2020. Comprehensive analysis of the state of crime in the Russian Federation at the end of 2019 and its development trends: Analytical review. In All-Russian Research Institute of the Ministry of Internal Affairs of the Russian Federation.

Grum-Grshimailo, G.E. 1926. Western Mongolia and Uriankhai territory. In Anthropological and ethnographic sketch of these countries. Saint-Petersburg: State Russian Geographical Society.

Gumba, Deo, and Diakaria Traore. 2020. Mali's livestock theft is dangerously yoked with persistent insecurity. https://enactafrica.org/enact-observer/malislivestock-theft-is-dangerously-yoked-with-persistent-insecurity. Accessed 15 Sept 2021

Harkness, Alistair. 2020. Rural crime prevention: Theory, tactics and techniques. London: Routledge. https://ab-centre.ru/page/selskoe-hozyaystvo-tyvy. Accessed 15 Sept 2021.

Jusupov, Bolotbek A., and Jarkyn J. Orozov. 2018. Theft of livestock in the Kyrgyz Republic as a sustainable crime and the measures to combat with them. European Science Review 7-8: 320-322. 
Karpova, N.A. 2011. Theft of someone's property: Issues of qualification and problems of differentiation of criminal liability. Moscow: Jurisprudencia Publ.

Katanov, N.F. 2011. Essays on the Uryankhai land. In Diary of a journey performed in 1889 on behalf of the Imperial Academy of Sciences and the Imperial Russian Geographical Society. Kyzyl: Tuvan Institute for Humanitarian and Applied Socio-Economic Research under the Government of the Republic of Tyva.

Khanov, Talgat A, and Kairat K Birzhanov. 2016. Forensic characteristics of the personality of a cattle stealer: Based on the materials of the Republic of Kazakhstan. http:apeljournal.ru/index.php/journal/article/view/462/0. Accessed 12 Sept 2021.

Khoabane, Selloane, and Philip A. Blac. 2009. The effect of livestock theft on household poverty in developing countries. In The case of Lesotho (No. 02) 2009). Stellenbosch: Stellenbosch University, Department of Economics.

Kisel, Vladimir A. 2018. The image of Kaigal in Tuvan culture (emotional perception and political situation). Kunstkamera 2: 153-161. https://doi.org/1 0.31250/2618-8619-2018-2-153-161.

Kiseleva (Chernousko) E. 2012. The personal factor in the formation of Tuvan statehood on the example of the activities of I. G. Safyanov (1917-1921). Bulletin of Tomsk State University 355: 61-63.

Kon, F.J. 1936. For 50 years. Moscow: Soviet writer Publ.

Kozin, S.A. 1941. Secret legend: Mongolian chronicle of 1240 called Mongol un niruča tobèj an. Moscow: Academy of Sciences Publ.

Manning, Louise, Robert Smith, and Jan Mei Soon. 2016. Developing an organizational typology of criminals in the meat supply chain. Food Policy 59 44-54. https://doi.org/10.1016/j.foodpol.2015.12.003.

Maphane, Obakeng, Oduetse Matsebe, and Molaletsa Namoshe. 2017. Development of electronic control circuits for WSN: Towards a Livestock tracking and identification system. American Journal of Engineering and Applied Sciences 10 (4): 781-789. https://doi.org/10.3844/ajeassp.2017.781.789.

Masiola, Rosanna, and Renato Tomei. 2015. A global crime and world hunger. In Law, language and translation, 35-46. Cham: Springer. https://doi.org/10.1 007/978-3-319-14271-5_4.

Ministry of Agriculture of the Russian Federation. 2006. Rules for organizing work on the issuance of accompanying veterinary documents. https://www.fsvps.ru. Accessed 12 Sept 2021

Ministry of Internal Affairs for the Republic of Tyva. 2019. Tuvan police officers remind about administrative responsibility for uncontrolled cattle grazing. https://17.xn\%2D\%2Db1aew.xn\%2D\%2Dp1ai/news/item/15748282. Accessed 15 Sept 2021

Ministry of Internal Affairs for the Republic of Tyva. 2021. Officials' reports. https://17.xn\%2D\%2Db1aew.xn\%2D\%2Dp1ai/slujba/Otcheti_dolzhnostnih_lic. Accessed 15 Sept 2021.

Ministry of Internal Affairs in the Republic of Tyva. 2018. The Ministry of Internal Affairs in the Republic of Tyva is taking a set of measures to combat animal stealing. https://17.xn\%2D\%2Db1aew.xn\%2D\%2Dp1ai/news/item/14295467. Accessed 15 Sept 2021

Mongush, A. 2019b. The criminogenic peculiarity of crimes related to the suppression of the state border in the regions of the Republic of Tuva bordering on Mongolia. Modern ethnic processes in the territory of Central Asia. Problems and Prospects 1: 100-104.

Mongush, A.S. 2013. Forensic characteristics of livestock thefts in the Republic of Tuva. Kyzyl: TuvSU Publ.

Mongush, A.S.O. 2019a. The problems of animal stealing in the Republic of Tuva: Analysis of investigation practice and countermeasures. Vestnik of Tuvan State University, Social Sciences and Humanities 2 (44): 47-55.

Mongush, D.A. 2011. Dictionary of the Tuvan language. Novosibirsk: Nauka Publ. Mongush, Kenin-Lopsan. 1999. Тыва чоннуң ыдыктыг чаңчылдары. Tuvan traditions. Book two: Sacred traditions of the Tuvan people.

Natsak, O. 2021. Legal status of Tuvinian women through the prism of laws of the Tuvinian People's Republic. New studies of Tuva 1: 148-173.

Official portal of the Republic of Tuva. 2014. In Tuva, the number of thousandstrong shepherds is increasing due to young livestock breeders. https://rtyva.ru/ press_center/news/agriculture/6763/. Accessed 15 Sept 2021.

Official portal of the Republic of Tuva. 2018. A regional conference on combating crime was held in Tuva. https://rtyva.ru/press_center/news/society/38359/. Accessed 15 Sept 2021.

Official portal of the Republic of Tuva. 2021. History of Tuva. https://rtyva.ru/ region/history/ Accessed 15 Sept 2021.

Official website of the Plenipotentiary Representative of the President of Russia in the Siberian Federal District. n.d. Siberian Federal District. County passport. Tuva Republic. Official website of the Plenipotentiary Representative of the
President of Russia in the Siberian Federal District. http://sfo.gov.ru/okrug/ TY/. Accessed 15 Sept 2021.

Olaniyan, Azeez, and Aliyu Yahaya. 2016. Cows, bandits, and violent conflicts: Understanding cattle rustling in Northern Nigeria. Africa Spectrum 51 (3): 93105. https://doi.org/10.1177/000203971605100305.

Oorzhak, K.D.K. 2019. Ethnoeconomics of Tuva: Current state and development prospects. Journal of International Economic Affairs 9 (3): 1759-1774.

Oorzhak, K.D.K. 2020. Prospects for the economic development of rural areas of the Tyva Republic. Economy of Central Asia 4 (1): 65-76.

Potanin, A.V. 1895. From travels in Eastern Siberia, Mongolia, Tibet and China. Moscow: Nauka.

Radlov, V.V. 2007. From Siberia. Diary pages (extract). Moscow: Slovo Publ.

Shcheblyakov, Evgeny. 2020. Forensic features of the theft of domestic animals (livestock). Humanities, Socio-Economic and Social Sciences 2: 192-195.

Weinstein, S. 1991. History of Tuva, 1991, 5, 61, DOI: https://doi.org/10.1155/S1073 792891000089.

World Bank. 2020. Moving towards sustainability: The Livestock Sector and the World Bank. https://www.worldbank.org/en/topic/agriculture/brief/movingtowards-sustainability-the-livestock-sector-and-the-world-bank. Accessed 15 Sept 2021.

Yakovlev, E.K. 1900. Ethnographic overview of the non-native population of the Southern Yenisei valley and an explanatory catalog of the Ethnographic Department of the Museum. Minusinsk: V. I. Kornakov's Printing House.

Yochelson, Samuel, and Stanton Samenow. 1993. The criminal personality: A profile for change. Vol. 1. Lanhan, Boulder, New York, Oxford: Jason Aronson.

\section{Publisher's Note}

Springer Nature remains neutral with regard to jurisdictional claims in published maps and institutional affiliations.

\section{Submit your manuscript to a SpringerOpen ${ }^{\circ}$ journal and benefit from:}

- Convenient online submission

- Rigorous peer review

- Open access: articles freely available online

High visibility within the field

- Retaining the copyright to your article

Submit your next manuscript at $\boldsymbol{\nabla}$ springeropen.com 